\title{
EFFECT OF ENTREPRENEURSHIP EDUCATION ON UNEMPLOYMENT REDUCTION IN ANAMBRA STATE, NIGERIA
}

\author{
${ }^{1}$ OKOYE, V. C., ${ }^{2}$ NWAKOBY, N.P and ${ }^{3}$ EZIKE, E.N \\ ${ }^{1}$ Department of Business Administration \\ Chukwuemeka Odumegwu Ojukwu University Igbariam, Anambra State, Nigeria \\ 2 Department of Entrepreneurship \\ Nnamdi Azikiwe University Awka \\ ${ }^{3}$ Department of Business Administration \\ Chukwuemeka Odumegwu Ojukwu University Igbariam, Anambra State, Nigeria
}

\begin{abstract}
The study examined the effect of entrepreneurship education on unemployment reduction in Anambra State, Nigeria. The specific objectives of the study were as follows, examine the effect of innovation on unemployment reduction in Anambra state in Nigeria: determine the effect of skill acquisition on unemployment reduction in Anambra state in Nigeria, evaluate the effect of access to finance on unemployment reduction in Anambra state in Nigeria, evaluate the effect of infrastructural development on unemployment reduction in Anambra state in Nigeria. Questionnaire was used to collect data from unemployed youths from the selected local government areas. Kirzner's Theory of Entrepreneurship was adopted in this study. The population of the study was 4,177,828 inhabitants in Anambra state, and a sample size of 399 was determined using Taro Yemane. The research adopted sampling technique such as purposive sampling. From the analyses tested, the study found out that, innovation has significant effect on unemployment reduction in Anambra state, entrepreneurship development has significant effect on unemployment reduction in Anambra state in Nigeria, bank credit has significant effect on unemployment reduction in Anambra state, infrastructural development has significant effect on unemployment reduction in Anambra state, Nigeria. The study recommended that Government must ensure necessary modifications in the educational system in the country that would make graduates to be employers of labour and self-employed, instead of looking for scarce job opportunities. The acquisition of the right skills to fit the various needs of the society is imperative. Adequate financial, physical resources as well as low interest rate fund should be provided by various stakeholders not only for potential but also for existing entrepreneurs.
\end{abstract}

Keywords: Entrepreneurship education, unemployment reduction, Innovation, Infrastructural development, skill acquisition 


\subsection{INTRODUCTION}

Entrepreneurship education and training cover the key part of entrepreneurial activity and support good practical exchange of activities such as the initiation, creations and sales of unique products to meet consumer need (Gabadeen \& Raimi, 2012). Entrepreneurship education and training should give an entrepreneur the opportunity to run any form of business successfully, as it develops the core skills and competences that entrepreneurs need to be successful and independently make quality decision that can affect productivity and competitiveness in innovation. Entrepreneurship education should expose youth entrepreneurs to new technology and related issues to enable them survive in the competitive environment.

Coduras, Jonathan, Donna, Rognovaldur and Thomas (2019) on the importance of entrepreneurship education and training, stressed that "... while education is one of the most important foundations for economic development, entrepreneurship is a major driver of innovation and economic growth. Entrepreneurship education plays an essential role in shaping attitudes, skills and culture from the primary level up to tertiary level. It is obvious that entrepreneurial skills, attitudes and behaviors can be learned, and that exposure to entrepreneurship education throughout an individual's lifelong learning path, starting from youth and continuing through adulthood into higher education as well as reaching out to those economically or socially excluded is imperative." (P.9). Hence, youths should be educated to strengthen the entrepreneurial potentials in them.

Entrepreneurship education has continued to feature as a captivating theme in local summits and international conferences because of its potency as tool for mitigating unemployment and other social-economic challenges inhibiting sustainable development in all parts of the globe. Nigeria adopted entrepreneurship education to accelerate economic growth and development. This reflects in Nigeria's national policy on education which states that education is the most important instrument for propelling change, as no fundamental change can occur in any society except through educational revolution that impact on the intellects (Federal Government of Nigeria, 2017). Entrepreneurship education is not a new phenomenon in the annals of Nigeria; it has always been an age-long tradition, a culture and a habit that has consistently been transferred from one generation to another within the diverse ethnic nationalities that made up Nigeria. Entrepreneurial mind-set is prevalent in Yoruba land in western Nigeria, Hausa land in the northern Nigeria and among the Igbo people of eastern Nigeria (Raimi, Shokunbi \& Peluola, 2010).

Entrepreneurship education is a functional education which can be used as a panacea for unemployment, and poverty eradication for national security, because entrepreneurship education has remained the major instrument for national development for many countries of the world. That is the reason most nations of the world spend huge sums of money to provide education for their citizens. Thus entrepreneurship education becomes a veritable platform for tackling socio-cultural, economic, political, scientific and technological challenges facing many nations. According to Agi \& Yellowe (2013), entrepreneurship education is important to the development of human resources, impartation of appropriate skills, knowledge and attitude. It is the basis for transformation, industrialization and a high way to global knowledge economy relating to security. 
Agi and Yellowe (2013) explained further that entrepreneurship education is regarded as a means of achieving culture of peace, gender equality, and positive African values. It is therefore the understanding of many that entrepreneurship education leads to national transformation and development, through reduction in poverty with ensured peace and security. The National Economic Empowerment and Development Strategy (2004) document show credence to the place of entrepreneurship education by clearly explaining its role in self-reliance and development of a state. Agi and Yellowe (2013) also supports this when they asserted that the goals of wealth creation or generation, poverty reduction and value reorientation can only be attained and sustained through an efficient education system which impacts the relevant skills, knowledge, capacities, attitudes and values. In view of the benefits of entrepreneurship education enumerated above, Nigeria has provided entrepreneurship education for decades with abundant available manpower.

Entrepreneurship education generates growth because it serves as a vehicle for innovation, change, and a conduit for knowledge spillovers. Thus, in a regime of increased globalization, the comparative advantages of modern economies are shifting towards knowledge based economic activity, not only do entrepreneurship play a more important role, but also a recommendation for economic growth (Deakins, and Freel, 2019). Education remains a vital transformational tool and formidable instrument for socio-economic empowerment, wealth creation, and employment generation, poverty alleviation and value orientation which government has talked about for so long now. Suffice it to be mentioned that education, training and experience can increase the supply of entrepreneurs by making available more skills which are suitable for entrepreneurial endeavour. Entrepreneurship education involves the willingness of persons to persistently pursue the opportunity to create wealth (Elkington 2011).

\subsection{Statement of the Problem}

One of the problems confronting many developing nations is how to combat the problem of unemployment with entrepreneurship development as seen by many as the lasting solution to it (Dandago, \& Muhammad, 2014). However, after many years of entrepreneurship development implementations in Nigeria, there are still many youths (graduates of Universities and Polytechnics and Colleges of Education) with wrong mindset of searching for nonexistent jobs or jobs where they will be underemployed or extreme jobs which they have no training or skills for. Although, several attempts have been made at encouraging entrepreneurial activities in Nigeria in the past, youths with entrepreneurial skills have not emerged. It is therefore, not totally surprising that only minimal success and achievement has been recorded particularly in areas requiring relatively low level skills.

While none of the past initiatives is completely without merits, the truth is that they did not have a significant, lasting and sustainable positive effect on the larger economy (Cyril \& Chijioke, 2010). According to Dandago (2014), this shows that without appropriate intervention to halt the unemployment situation in Nigeria, more youths will become unemployed with varying consequences to youth development, national development and National Security. It is against this backdrop that the study sought to examine the effect of entrepreneurship on economic sustainability in Nigeria. 


\subsection{Objectives of the Study}

The broad objective of this study is to examine the effect of entrepreneurship education on unemployment reduction in Anambra state in Nigeria: specifically, the study intended to:

1. Examine the effect of innovation on unemployment reduction in Anambra state in Nigeria

2. Determine the effect of skill acquisition on unemployment reduction in Anambra state in Nigeria

3. Evaluate the effect of Access to finance on unemployment reduction in Anambra state in Nigeria

4. Evaluate the effect of infrastructural development on unemployment reduction in Anambra state in Nigeria

\section{REVIEW OF RELATED LITERATURE}

\subsection{Theoretical Framework}

\subsubsection{Kirzner's Theory of Entrepreneurship}

According to Kirzner (1973), an entrepreneur is someone who is alert to and perceives profitable opportunities for exchange. Recognizing the possibilities for exchange enables the entrepreneur to benefit by acting as middleman who facilitates the exchange. The Kirzner's entrepreneur is an intermediary who is alert to opportunities to trade. He is able to identify suppliers, customers and act as intermediary. To Kirzner, everybody can be an entrepreneur or has the potential of being an entrepreneur. The entrepreneur is not a simple maximize, facing given ends and means, but a homo agent as postulated by Kirzner. The entrepreneur discovers new ends and new means and has 'drive' and alertness. Kirzner defines the entrepreneurial element as alertness to possibly new worthwhile goals and to possibly new available resources. This element makes human action 'active, creative and human rather than passive, automatic, and mechanical'. Kirzner maintains that a pure entrepreneur has no need to possess any other resources, because he can hire 'all the talents needed to organize factors of production into a smoothly working team.' He is not therefore, a 'producer' in the normal sense. Because of the absence of need for additional resources, everyone is a potential entrepreneur, provided that he has the necessary quality of alertness to profitable opportunities.

\subsection{Empirical Review}

Oladeji (2019) assessed the level of impact this programme has on Youth empowerment and development in the Ondo State. Youths are said to be the future leaders of any country in the world, Nigeria inclusive. It is also a general belief that government all over the world try to invest strategically in her youth for them to be able to assume the position of leadership when the time comes. In spite of this, it appears that the training, the investment of the Nigerian governments as well as the socialization of youth in Nigeria and Ondo State, in particular, seem to be inadequate because many of them instead of contributing meaningfully to the development of the society, they are doing otherwise 27 copies of the questionnaire were administered on the trainers at the skill acquisition centers, while 557 copies were given to 
the beneficiaries of the skills acquisition programme in Ondo State. Thirteen members of the coordinating departments were chosen for an in-depth interview. Findings revealed that the skills acquisition programme has been able to provide employment opportunities for youth beneficiaries, reduce their involvement in social vices, improved their standard of living.

Agbogo \& Azih, (2015) designed to find out the role of skills acquisition centres in poverty reduction in Obudu and Ogoja Local Government Areas of Cross River State, Nigeria. Three specific purposes and corresponding research questions and four null hypotheses guided the study. The study employed survey research design. The population of the study was three hundred and seventy two (372) artisans who participated in the skills acquisition programme between 2009 and 2011which is made up of one hundred and ninety-four (194) male and one hundred and seventy-eight (178) female artisans. There was no sampling since the entire population was small. An instrument titled: Skill Acquisition Centres and Poverty Reduction Questionnaire (SACPRQ) was designed to elicit information from the respondents. Data obtained for the study were analyzed using mean and standard deviation to answer all research questions and t-test statistic was used to test all the hypotheses at 0.05 level of significance. The results revealed that the training programmes impacted to a large extent on the social and economic lives of the participants as well as reduced the level of poverty in Obudu and Ogoja Local Government Areas.

Oluwakemi Olawale \& Qudus (2018) investigated effectiveness of entrepreneurial skills acquisition as a tool for employment generation among polytechnic graduates in Nigeria. The study seeks to determine the stance of higher education and entrepreneurial skills acquisition in employment generation. The variables of interest are job orientation, job creation and selfemployment; and its associated self-reliance, job satisfaction on employment generation. A descriptive design was adopted with a multi-stage sampling technique in selecting a sample size of 647 Batch B stream 2 Corp members from public polytechnics in Southwest, Nigeria. A multiple regression inferential statistics was applied in data analysis. The findings established that the state of higher education in entrepreneurship have no significant effect on employment generation. However, in Nigeria, other findings revealed that entrepreneurial skills acquisition increases job orientation, job creation and self-employment. It is therefore obvious that entrepreneurial skills ${ }^{\text {ee }}$ acquisition can lead to self-employment if strategically positioned.

Ekong \& Ekong, (2018) investigated how Unemployment problem is tackled through Skills Acquisition by the National Directorate of Employment (NDE) in Akwa Ibom State, Nigeria. Different measures have been adopted by the government to tackle the challenge with very little result. Using data obtained from both primary and secondary sources for the period 1987-2012, we found that positive link exist between Skills Acquisition by NDE and Unemployment reduction in Akwa Ibom State even though not without daunting challenges. However, the results of the income contributions of Skills Acquisition by NDE to the States' economy were mixed. While $48 \%$ asserted to a positive link, $40 \%$ accepted a minimal influence. Thus, we recommend more spread of NDE training centers to all the Local Government Areas in the State for more benefits to be realized, among others.

Iyaji, Achoba, \& Kolawole (2018) examined the role of vocational training in curbing unemployment in Nigeria. The methodology employed is research survey field visits, interaction with stakeholders of vocational skills graduates. In addition, secondary data were used. The results were presented using discrete statistics and tables. The result revealed that 
vocational skills development is a fertile avenue for creating employment in Nigeria. Vocational skills acquisition is also identified to be an area which if keyed into could go a long way in ameliorating the negative impact of unemployment in Nigeria. The study concluded that with willingness and determination the skill acquired from a vocational centre the prospective graduate may not have to look for paid employment and hence this avenue could go a long way to reduce unemployment to a large extent. Thus, the study recommends that vocational skill acquisition is strengthened in Nigerian tertiary institutions so that such graduates could be self-employed thereby contributing the aggregate socio-economic fortunes of the nation.

Solaja, \& Adenuga (2016) examined the impact of skill acquisition programmes on graduate unemployment rate in Lagos State, Nigeria. The Refugee effect and Schumpeter effect on unemployment and entrepreneurship was employed as theoretical guide. Descriptive survey designed was adopted for the study. Sample size comprised of 326 students of 4 Skill Acquisition Centres (SACs) in selected Local Government Areas of Lagos State, Nigeria. The selection of the respondents was done through multi-stage sampling technique. Semistructured questionnaire was used for data collection. Data were analyzed using descriptive and inferential statistics. The finding revealed that skill acquisition programmes have direct influence on graduate unemployment reduction in Lagos State, Nigeria. It also promotes culture of creative ideas, self-reliance, business initiative as well as low level of dependency among the youths in Lagos State, Nigeria. Thus, it was recommended that more efforts in terms of funds, facilities and materials must be provided by the government and nongovernmental organizations to expand the capacity of skill acquisition programmes in Nigeria in order to help actualize the dream and vision of a better life for the youths.

Okolocha, John-Akamelu, and Muogbo (2020) examined the effect of skill acquisition programme on youth employability in Nigeria. For the purpose of this study, undergraduate, graduates and post graduate individuals of Anambra State were used. The main instrument used was the structured questionnaire. 100 respondents were randomly selected from different local governments in Anambra State. Findings revealed that much emphasis on academic excellence, lack of quality skilled trainers, acute shortage of facilities, inconsistent follow up by government and poor funding are problems facing skills acquisition employment in Nigeria. Based on the premises of the findings it was recommended that teachers require professional skills development abilities, competence, years of experience through understanding of the subject matter and effective involvement of the student in the instructional delivery.

Ezeanokwasa \& Nwachukwu, (2014) examined the effective entrepreneurship skills in reducing unemployment through small business innovation in Nigeria. The research design used for this research work was descriptive research design. The questionnaire was the instrument distributed to the participants. Frequencies, arithmetic means, standard deviations and t-statistics were used to analyze the data. The findings of the study showed that the contribution of entrepreneurship skills towards reducing unemployment in Nigeria include improvement in the standard of living through innovation that led to introduction of high goods and services and conservation of foreign exchange as a result from reduced importation of machines and equipment, raw material and payment to foreign export. It was found also that there is significant relationship that exists between effective entrepreneurial skills and unemployment in Nigeria. 
Orji, Nwosu, and Mba, (2019) estimated the impact of ICT usage on unemployment rate in Nigeria from 1985-2015. Adopting a classical linear regression model with data from the National Bureau of Statistics (NBS), the results reveal that within the period under review, ICT had a significant positive impact on unemployment rate in Nigeria. The study therefore concludes that ICT innovations can help the Nigerian unemployment situation through different channels but the government and other policy makers must be pro-active in adopting useful policies and strategies that will enhance ICT penetration and usage in critical sectors of the economy.

Kristina, Mindaugas and Akvile (2019) analysed theoretical and empirical scientific literature about the impact of technological innovations on unemployment, considering the former as a key driver of long-term productivity and economic growth. Using panel data from 25 European countries for the period of 2000-2012, we aim to examine whether technological innovations affect unemployment. We used triadic patent families per million inhabitants as our main proxy for technological innovations, as well as other unemployment controls, in our model, which were estimated using System Generalized Method of Moments (SGMM). Finding no significant relationship between technological innovations and unemployment in our base estimation, we re-estimated it testing the impact with a time lag as well as using alternative proxies for technological innovations. Overall, the research estimations do not suggest that technological innovations have an effect on unemployment.

Ogah, \& Adebayo, (2014) explored information and communication technology: a panacea for alleviating unemployment in Nigeria. This nation that has been entangle with various issues of unemployment affecting most citizens. Many vibrant citizens with strong potential and zeal to contribute to the status of Nigeria are not cohort into the working class. There is need to acquaint themselves with the information and communication technology that add value to them. It has various opportunities for job seekers in the area of web design, business centre, graphic design; data programming etc. Unemployment creates negative impact on the standard of living of entire citizenry. Unemployed can be describe as numbers of the economically active population who are without work but available for and seeking work, including people who have lost their jobs and those who have voluntarily left work.

\section{METHODOLOGY}

According to (Adams, 2010), research design describes a number of decisions which need to be taken regarding the collection of data before ever the data is collected; A schematic guide which directs a researcher in solving research problem. The most crucial operation in the execution of a research work is collection of data because such information and data are necessary for arriving at the solution of the problem being investigated. Undergoing research of this nature calls for the use of both primary and secondary sources of data to make the work more reliable. Population is the totality of any group, persons or object which is defined by unique attributes. In other words, population is any groups that have even been focused upon the researcher. To have an extensive courage of this study, the research will use the population of Anambra State which is $4,177,828$. The study used stratified random sampling method for selecting respondents. This approach is preferred because it involves dividing the population into homogeneous subgroups and then taking a simple random sample in each group (Kombo and Tromp, 2006). There are three senatorial districts in the state, namely: (a) Anambra North, comprising Awka North and South, Njikoka, Dunukofia, Anaocha, and Idemili North and South Local Government Areas (LGAs); (b) Anambra Central, made up of 
Onitsha North and South, Ogbaru, Oyi, Ayamelum, and Anambra East and West LGAs; and (c) Anambra South consisting of Orumba North and South, Aguata, lhiala, Ekwusigo, and Nnewi North and South LGAs. To have an extensive courage of this study, the researcher selected one local government from each senatorial zone making it a total number of three local government councils. Sample size $=399$ Questionnaire instrument was used in this study for collection of data. The questionnaire items were administered by hand and collected in the same manner by the researcher and with the help of five research assistants. Statistics such as frequency count and percentages were put to use in the analysis of research questions while research hypotheses were tested using correlation analysis and simple regression analysis. The research hypotheses were tested at 0.05 level of significance. Analysis was carried out with the aid of Statistical Package for Social Sciences (SPSS).

\section{PRESENTATION ANALYSIS AND INTERPRETATION OF DATA}

This chapter presents the data obtained from the respondents through the administered questionnaire. Three hundred and ninety-nine (399) were administered among the youths of selected L.G.A. However, three hundred and forty-seven (347) copies of questionnaire were retrieved. Therefore, the analysis and interpretation of data were only based on the returned questionnaire.

\subsection{Demographic Characteristics of the Respondents}

\begin{tabular}{|c|c|c|c|c|}
\hline & & Frequency & Valid Percent & $\begin{array}{c}\text { Cumulative } \\
\text { Percent }\end{array}$ \\
\hline \multirow{3}{*}{ Valid } & MALE & 172 & 49.6 & 49.6 \\
\hline & FEMALE & 175 & 50.4 & 100.0 \\
\hline & Total & 347 & 100.0 & \\
\hline
\end{tabular}

\section{Sources: SPSS Output 2021}

The above table reveals that the one hundred and seventy-two of the respondents which represents 49.6 persons were male respondents, while one hundred and seventy-five (175) respondents which represent $50.4 \%$ were female respondents. By implication, female respondents were more than male respondents by 3 respondents in our selected population sample for this study. The implication of this is to enable us to know the number of female and male that successfully returned their questionnaire. 


\subsubsection{STATUS}

\begin{tabular}{|c|c|c|c|c|}
\hline & & Frequency & Valid Percent & $\begin{array}{c}\text { Cumulative } \\
\text { Percent }\end{array}$ \\
\hline \multirow{3}{*}{ Valid } & MARRIED & 252 & 72.6 & 72.6 \\
\hline & SINGLE & 95 & 27.4 & 100.0 \\
\hline & Total & 347 & 100.0 & \\
\hline
\end{tabular}

\section{Sources: SPSS Output 2021}

In the table above, out of the three hundred and forty-seven (347) respondents, two hundred and fifty-two (252) of the respondents were married, while ninety-five (95) respondents which represent 27.4 percent are single. It is therefore glaring that the majority of the respondents are married as at the time of this study. Thus marital status table help us to know the number of single, and married-respondents that answered the distributed questionnaire.

\subsubsection{LEVEL OF EDUCATION}

\begin{tabular}{|c|c|c|c|c|}
\hline & & Frequency & Valid Percent & $\begin{array}{c}\text { Cumulative } \\
\text { Percent }\end{array}$ \\
\hline \multirow{5}{*}{ Valid } & WAEC & 238 & 68.8 & 68.8 \\
\hline & $\mathrm{BSC} / \mathrm{HND}$ & 62 & 17.9 & 86.7 \\
\hline & MSC & 36 & 10.4 & 97.1 \\
\hline & OTHERS & 10 & 2.9 & 100.0 \\
\hline & Total & 347 & 100.0 & \\
\hline
\end{tabular}

Source: Field Survey 2021

The table above indicates that two hundred and thirty-eight (238) respondents which represent $68.8 \%$ percent maintain to have acquired WAEC while $17.9 \%$ percent of the respondents which represents sixty-sixty (68) have BSC/HND. However thirty-six respondents which represent 10.4 percent either have MSC. Meanwhile, 10 respondents were for other certificates. This as one of the demographic item helps us to identify the education qualification of the respondents. 


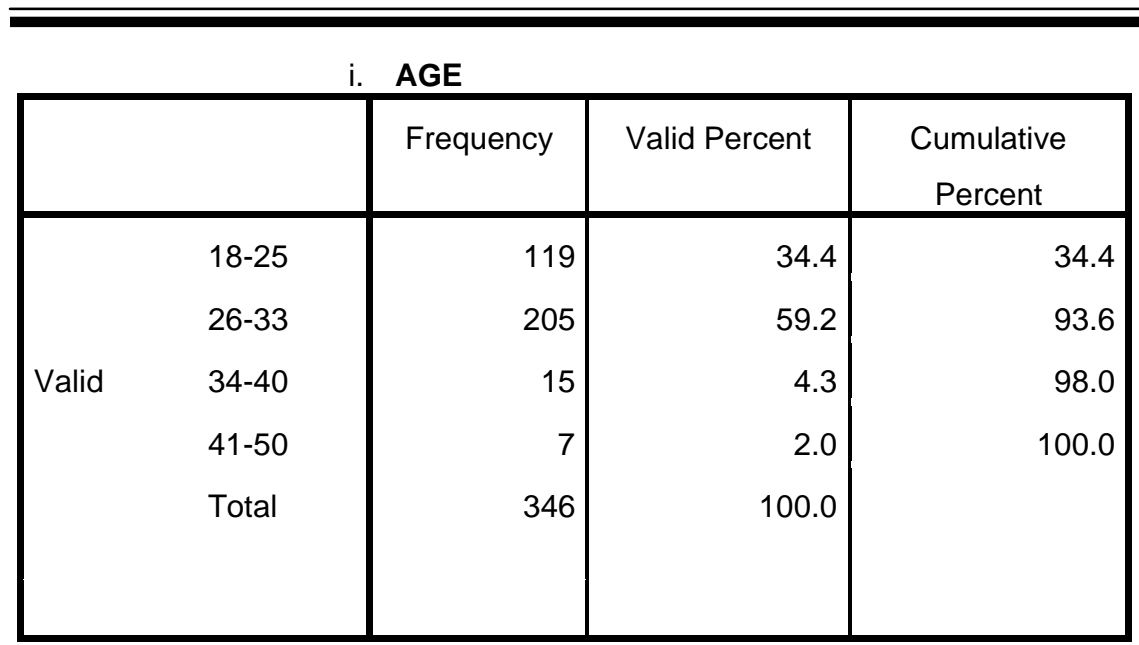

Source: Field Survey 2021

Table above depicted the age bracket of the respondents. The distribution shows that $34.4 \%$ of the respondents are between the age brackets of 18 to 25 years while $59.2 \%$ respondents are within the age bracket of 26-33 years. On the same note, $4.3 \%$ of the respondents are within the age bracket of $34-40$ years. More so, $2.0 \%$ of the respondents are within the age bracket of $41-50$ years.

Table 4.2 Multiple Regression Analysis

\begin{tabular}{|c|c|c|c|c|c|c|}
\hline \multicolumn{2}{|c|}{ Model } & Sum of Squares & df & Mean Square & $\mathrm{F}$ & Sig. \\
\hline \multirow[t]{3}{*}{1} & Regression & 312.746 & 4 & 78.187 & 164.680 & $.000^{\mathrm{b}}$ \\
\hline & Residual & 84.510 & 178 & .475 & & \\
\hline & Total & 397.257 & 182 & & & \\
\hline
\end{tabular}

a. Dependent Variable: UNR

b. Predictors: (Constant), INFD, INV, SAQ, ATF

The F- statistics: This is used to test for the overall significance of the model. From the result in table above, our computed value of F- statistics is 164.680 , while the probability is 0.0000 . Since the probability of the F- statistics in the computed output is less than the desired 0.05 level of significance, we accept and state that there is a significant relationship between the variable of the estimate and that of the dependent variable. 


\subsubsection{Coefficients ${ }^{a}$}

\begin{tabular}{|c|c|c|c|c|c|c|c|}
\hline \multirow[b]{2}{*}{ Model } & \multicolumn{2}{|c|}{$\begin{array}{c}\text { Unstandardized } \\
\text { Coefficients }\end{array}$} & \multirow{2}{*}{$\begin{array}{c}\begin{array}{c}\text { Standardized } \\
\text { Coefficients }\end{array} \\
\text { Beta } \\
\end{array}$} & \multirow[b]{2}{*}{$t$} & \multirow[b]{2}{*}{ Sig. } & \multicolumn{2}{|c|}{$\begin{array}{c}95.0 \% \text { Confidence Interval } \\
\text { for B } \\
\end{array}$} \\
\hline & B & Std. Error & & & & $\begin{array}{l}\text { Lower } \\
\text { Bound }\end{array}$ & Upper Bound \\
\hline (Constant) & -1.369 & .177 & & -7.711 & .000 & -1.719 & -1.018 \\
\hline SAQ & .206 & .047 & .165 & 4.385 & .000 & .113 & .299 \\
\hline ATF & .470 & .055 & .415 & 8.579 & .000 & .362 & .578 \\
\hline INFD & .145 & .049 & .111 & 2.951 & .004 & .048 & .241 \\
\hline
\end{tabular}

a. Dependent Variable: UNR

A'priori Criteria: This is determined by the existing business theories; it also indicates the signs and magnitude of the business parameter under review. In table above, we find out that innovation (INV) has a positive sign given its value as 0.747 ; this implies that a unit increase in innovation reduces the unemployment rate by $74 \%$, this conforms to the a' priori expectation. Skill acquisition (SAQ) has a positive sign and its value is 0.206 ; this implies that a unit increase in Skill acquisition reduces the unemployment rate by $20 \%$, this also conforms to theoretical expectations. Access to finance (ATF) has a positive sign and its value as 0.470 ; this implies that a unit increases in Access to finance reduces unemployment rate by $47 \%$; this conforms to a' priori expectation. Lastly it was observed that infrastructural development (INFD) has positive sign given its value as $0.145 \%$ this implies that a unit increase in infrastructural development reduces the unemployment rate by $14 \%$, this also conforms to theoretical expectations and organizational performance in Anambra state.

T- Statistics: This is carried out to measure the significance of individual explanatory variables in the model that is to find out the significant influence of explanatory variables on the dependent variables at chosen level of significance. It was discovered that innovation (INV) is statistically significant at $5 \%$ level, and this implies that it contributes significantly to unemployment reduction in Anambra State

Skill acquisition (SAQ) is positively significant at 5\% level. This implies that it is one of the determining factors of unemployment reduction as it contributes positively to unemployment reduction in Anambra state. Skill acquisition (SA) is also positively significant.

Access to Finance (ATF) is positively significant at 5\% level. This implies that it is one of the determining factors of unemployment reduction because it contributes positively to unemployment reduction in Anambra state. Lastly, infrastructural development has significant impact on unemployment reduction in Anambra state at $1 \%$ level of significance. 
4.2.3 Model Summary

\begin{tabular}{|c|c|c|c|c|c|c|c|c|c|c|}
\hline \multirow[b]{2}{*}{ Mode } & \multirow[b]{2}{*}{$\mathrm{R}$} & \multirow[b]{2}{*}{$\begin{array}{c}\mathrm{R} \\
\text { Square }\end{array}$} & \multirow[b]{2}{*}{$\begin{array}{c}\text { Adjusted R } \\
\text { Square }\end{array}$} & \multirow{2}{*}{$\begin{array}{l}\text { Std. Error } \\
\text { of the } \\
\text { Estimate }\end{array}$} & \multicolumn{5}{|c|}{ Change Statistics } & \multirow[b]{2}{*}{$\begin{array}{l}\text { Durbin- } \\
\text { Watson }\end{array}$} \\
\hline & & & & & $\begin{array}{c}\text { R Square } \\
\text { Change }\end{array}$ & $\begin{array}{c}\text { F } \\
\text { Change }\end{array}$ & df1 & df2 & $\begin{array}{l}\text { Sig. F } \\
\text { Change }\end{array}$ & \\
\hline 1 & $.887^{\mathrm{a}}$ & .787 & .782 & .68904 & .787 & 164.680 & 4 & 178 & .000 & 1.619 \\
\hline
\end{tabular}

a. Predictors: (Constant), INFD, INV, SAQ, ATF

b. Dependent Variable: UNR

\section{Interpretation of the Result}

The Coefficient of determination otherwise known as the goodness of fit explains the percentages, proportion or total amount of variations in the dependent variables as a result of changes in the independent variables included in the model. This portrays the usefulness or rather the significance of the regression. The closer its values are to 1 , the better the fit since the value is usually $0-1$.

From our regression result, $\mathrm{R}^{2}$ is $.87 \%$. This implies that the independent variables can explain about $87 \%$ of the variable in the dependent variable, leaving the remaining $13 \%$ which would be accounted for by other variable outside the model.

Test for autocorrelation: This is used test whether errors corresponding to different observation are uncorrelated. If the value of the durbin-watson from the regression result is close to 2 no autocorrelation in that regression result, but if it deviates significantly then there is autocorrelation. The Durbin-Watson statistic (D.W) of 2 reveals no autocorrelation in the models. Hence, the result is good for business analysis because the Durbin Watson result is 1.6

\subsection{Test of Hypotheses}

To further justify the results, ANOVA test was conducted to examine the relationship between entrepreneurship education on unemployment reduction in Anambra state in Nigeria. The results were shown in the ANOVA Table below;

\section{Hypothesis one}

Ho1: Innovation has no significant effect on unemployment reduction in Anambra state in Nigeria.

ANOVA

\begin{tabular}{|l|r|r|r|r|r|}
\hline & Sum of Squares & df & Mean Square & F & \multicolumn{1}{c|}{ Sig. } \\
\hline Between Groups & 1863344666.602 & 2 & 53238419.046 & 114.067 & .008 \\
Within Groups & 397198.932 & 344 & 397198.932 & & \\
Total & 1863741865.534 & 346 & & & \\
\hline
\end{tabular}

Source: SPSS Version 20, 2021

The test table reveal that small significance value $(\mathrm{F}$. sig<.05) indicate group differences. Since the F- value of 114.067 which has a significance of .008 is less than .05 (i.e $.001<.05$ ), 
there exist significant difference among the variables. Therefore, null hypothesis is rejected and alternative hypothesis is accepted, which states that Innovation has significant effect on unemployment reduction in Anambra state.

\section{Hypothesis Two}

Ho2: Skill acquisition has no significant effect on unemployment reduction in Anambra state

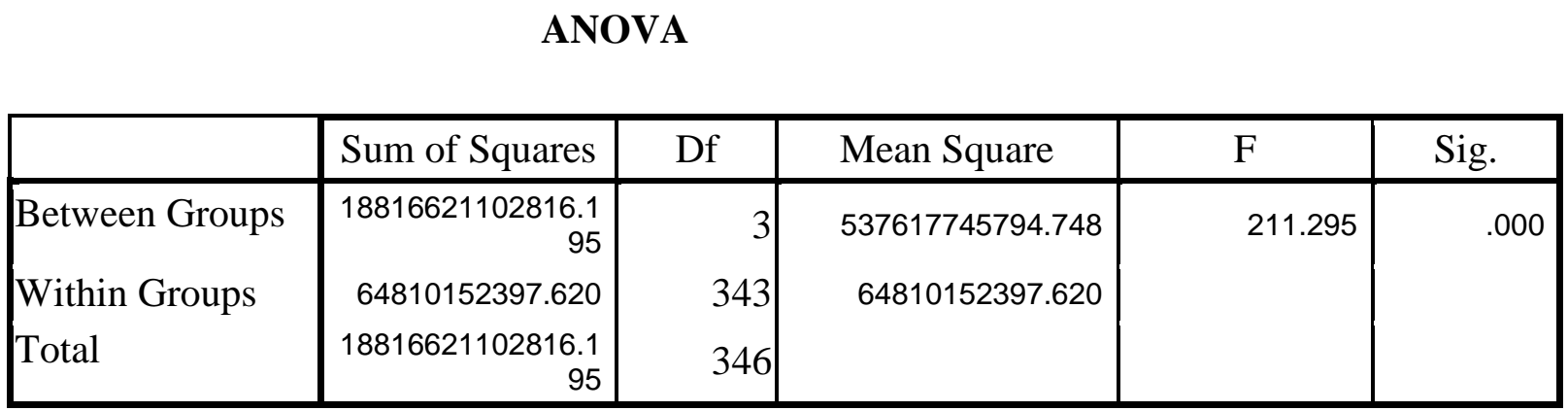

Source: SPSS, Version, 202021

The small significance value $(\mathrm{F} . \operatorname{sig}<.05)$ indicates that there is a group difference. Since the F-value of 211.295 which has a significance value of .000 is less than .05 (i.e $000<.05$ ). This implies rejection of null hypothesis and acceptance of alternative hypothesis which state that Entrepreneurship has no significant effect on unemployment reduction in Anambra state.

\section{Hypothesis Three}

Ho3: Access to finance has no significant effect on unemployment reduction in Anambra state.

ANOVA
\begin{tabular}{|l|r|r|r|r|r|}
\hline & Sum of Squares & Df & Mean Square & F & Sig. \\
\hline Between Groups & 881.762 & 4 & 25.193 & 213.295 & .000 \\
Within Groups & 3.511 & 342 & 3.511 & & \\
Total & 885.274 & 346 & & & \\
\hline
\end{tabular}

Source: SPSS, Version, 20, 2021

The test conducted revealed that the large significance value (F.sig<.002) indicate no group differences. Since the F-value of 213.295 with a significance of .002 is less than .05 (i.e $.002<.05)$, there is no significant relationship between coaching and entrepreneurial skill development. 


\section{Hypothesis Four}

Ho3: Infrastructural development has no significant effect on unemployment reduction in Anambra state.

ANOVA
\begin{tabular}{|l|r|r|r|r|r|}
\hline & Sum of Squares & Df & Mean Square & F & Sig. \\
\hline Between Groups & 881.762 & 2 & 25.193 & 93.290 & .008 \\
Within Groups & 3.511 & 1386 & 3.511 & & \\
Total & 885.274 & 1388 & & & \\
\hline
\end{tabular}

Source: SPSS, Version, 20, 2019

The test conducted revealed that the large significance value $(\mathrm{F} . \mathrm{sig}<.002)$ indicate no group differences. Since the F-value of 93.290 with a significance of .008 is less than .05 (i.e $.002<.05)$, infrastructural development has no significant effect on unemployment reduction in Anambra state.

\section{CONCLUSION AND RECOMMENDATION}

The study focused on the effect of entrepreneurship on unemployment reduction in Anambra state with reference to SMEs in Anambra state. The study adopts descriptive statistics. The study regressed entrepreneurship on unemployment reduction using one way ANOVA. The F-statistic is significant at the $5 \%$ level showing that there is a linear relationship between the entrepreneurship and economic growth. The result revealed that entrepreneurship development had significant effect on unemployment reduction, bank credit has significant effect on unemployment reduction, the researcher concluded that innovation and entrepreneurship development has significant effect on unemployment reduction in Nigeria. The benefits and need to go for technology development through either technology transfer or technological innovations or inter-firm linkages should be emphasized in the light of dimensions of global competition and its negative fall outs as well as positive opportunities, to small and medium scale industries entrepreneurs through seminars and work shop, at the local level. Government must ensure necessary modifications in the educational system in the country that would make graduates to be employers of labour and self-employed, instead of looking for scarce job opportunities. The acquisition of the right skills to fit the various needs of the society is imperative. Adequate financial, physical resources as well as low interest rate fund should be provided by various stakeholders not only for potential but also for existing entrepreneurs. Government must also urgently attend to the nagging issue of infrastructural deficits in the country especially that of power supply. The national economy need a strategic diversification from oil and gas to agriculture, aviation, tourism, manufacturing and these should become the real engine of growth and employment generation that will sustain the economic growth of Nigeria. 


\section{References}

Agbogo, R. A. \& Azih, N.(2015). Roles of skills acquisition centers in poverty reduction in Obudu and Ogoja local government areas of cross-river state. International Researchers 4 (3) 57-67

Agi U.K. and Yellowe N.A. (2013). Management strategies for regenerating secondary education for national development and self-reliance. Journal of Teacher Perspective (JOTEP) 7(2). Association of Nigerian Teachers (ASSONT) Calabar

Cyril O.,. \& Chijioke J.B (2010) Entrepreneurship and poverty reduction in Nigeria: An Empirical Analysis. Journal of Business and Management. 17(3): 16-19

Dandago, K. I. \& Muhammad, Y. M. (2014). Entrepreneurship development programmes and facilitation of youth employment in Kano state, Nigeria. European journal of academic research, 2 (1), 17-30.

Deakins, D. and Freel, M (2019). Entrepreneurship and small firms, $5^{\text {th }}$ edition, Internet Copy:McGraw Hill

Ekong,U.M \& Ekong, C.U (2018) Skills acquisition and unemployment reduction in nigeria: a case study of national directorate of employment (nde) in akwa ibom state. International Journal of Economics \& Management Sciences 5 (8) 352-367

Elkington J. (2011). Key traits of social entrepreneurs. Harvard Business Publishing. Available (online) at http://sciencetage.com/v/13869. Accessed 31/07/15.

Ezeanokwasa F. N. \& Olisa Philip Nwachukwu, N.P (2014). Effective entrepreneurship skills in reducing unemployment through small business innovation in Nigeria. Information and Knowledge Management 4 (11) 96-210

Gabadeen, W. O. and Raimi, L. (2012) Management of entrepreneurship education in nigerian higher institutions: issues, challenges and way forward. Abuja International Journal Of Education And Management Sciences 2, (7) 1-26

Iyaji, S. O,Achoba,M. I.\&Kolawole, O. B.,(2018). Role of vocational skills acquisition in reducing unemployment among architecture graduates in Nigeria. Journal of Good Governance and Sustainable Development in Africa. 4 (2) 146-157

Kristina M., Mindaugas B. and Akvile K. (2019). Do technological innovations affect unemployment? some empirical evidence from European countries 6 (3) 23-34

Ogah, A.V.\& Adebayo, A. P. (2014). Information and communication technology: a panacea for alleviating unemployment in Nigeria. International Policy Brief Series Education \& Science Journal, 4 (1), 205-227

Okolocha C. B,John-Akamelu C. Rand Muogbo U. S (2020). Effect of skill acquisition on youth employability in Nigeria. International Journal of Research in Finance and Management 2020; 3(1): 33-37 
Oladeji O. F. (2019). Skills acquisition programme and youth empowerment in Ondo State of Nigeria: an empirical study. Global Journal of Human-Social Science. 19 (6) 45-56

Oluwakemi O. O., Olawale L. A., Qudus O. A.(2018) Entrepreneurial skills' acquisition and employment generation among polytechnic graduates in south west, Nigeria. Journal of Humanities, 3(2): 273-284

Orji, A, Nwosu, E.O \& Mba, P.N (2019). ICT usage and unemployment rate nexus in Nigeria: an empirical analysis. Journal of banking and commerce 7 (5) 34-45

Raimi, L., Shokunbi,M. O. and Peluola, S.B. (2010)Entrepreneurship and development institutions in Nigeria: prospects and challenges. A chapter contribution in perspectives of entrepreneurship and economic development in nigeria edited by Dr. Kolawole Subair, Olad Publishers Nigeria Limited, Kwara, Nigeria.

Solaja, O. M. \& Adenuga, O. A.(2016). Investigating the impact of skill acquisition programmes on graduates unemployment dilemma in lagos state, Nigeria. St. Theresa Journal of Humanities and Social Sciences 2 (2) 16-34 